\title{
Morphometric Alterations Induced by the Toxicity of Variable Sizes of Silver Nanoparticles
}

\author{
Alteraciones Morfométricas Inducidas por la Toxicidad de \\ Diferentes Tamaños de Nanopartículas de Plata
}

Mansour Almansour*; Qais Jarrar**; Abdelkader Battah ${ }^{* * * *}$ \& Bashir Jarrar****

ALMANSOUR, M.; JARRAR, Q.; BATTAH, A. \& JARRAR, B. Morphometric alterations induced by the toxicity of variable sizes of silver nanoparticles. Int. J. Morphol., 33(2):544-552, 2015.

SUMMARY: Silver nanoprticles (SNPs) are invested in medical, industrial and environmental applications. Little if any, is known about the morphometric alterations induced by the toxicity of SNPs. The aim of the present work is to find out the effect of variable size of SNPs on different morphometric parameters. Adult healthy male mice (BAL/C) were subjected to $(10 \mathrm{~nm}, 20 \mathrm{~nm}, 40 \mathrm{~nm}$ $60 \mathrm{~nm}$ and $100 \mathrm{~nm}$ ) SNPs for 35 days. Silver NPs caused non-significant decline on the average weight, significant decline in food consumption, increase in water intake, unilateral blindness, tanning fur color and cholestasis together with a decrease in the relative ratio of the liver, kidney and spleen weight to body weight. Mice subjected to $10 \mathrm{~nm}$ and $20 \mathrm{~nm}$ were more affected than mice receiving larger nanoparticles. These findings may indicate that SNPs could induce morphometric alterations that are size related wheresmaller SNPs have more impact than the larger ones.

KEY WORDS: Silver nanoparticles; Morphology; Toxicology; Liver; Kidney; Spleen.

\section{INTRODUCTION}

Silver nanoparticles (SNPs) are being invested in nanomedicine and consuming products due to their unique properties (Luoma, 2008; Rai et al., 2012; Xue et al., 2012). These particles are used in coating medical instruments and tools such as vascular and urinary catheters, contraceptive devices, surgical instruments and others (Silver et al., 2006). In addition, SNPs are invested in medical cloth, footwear, athletic shirts and textile manufacturing to limit bacterial growth preventing odor causing bacteria proliferating due to sweating (Vigneshwaran et al., 2007; Turtle, 2012). Moreover, these fine particles are being used in biological and chemical sensors and in imaging of neural tissues (Ahamed et al., 2010). Many commercial brands of sunscreen, medical masks, gels, cosmetics, bone cement (prostheses), tooth paste, deodorants, dental resin composite, shampoo and laundry detergents include silver NPs (Jain et al., 2009; Turtle). These nanoparticles are included on the surface of some household appliances such as nano-silver refrigerators, -air conditions, and -washing machines
(Luoma). Also these particles are invested in toys, baby pacifiers, humidifiers and food storage containers (Hanson, 2011; Turtle).

Silver nanofibers are now used in bioengineering and some water filters in order to clean infected water (Jain \& Pradeep, 2005). These particles enter the environment through waste water treatment and the disposable food packaging with toxic potential to many forms of aquatic and terrestrial life and elicit behavioral, biochemical, physiological and neurological responses (Reijnders, 2006; Turtle; Oberdörster et al., 2007).

Studies showed that silver nanoparticles could accumulate mainly in the vital organs including liver, kidneys, lungs, spleen, endometrium and brain and considered to be toxic to these organs (Johnston et al., 2010; Ahamed et al.; Austin et al., 2012; Xue et al.; Kim et al., 2014). While some studies showed that SNPs can induce

* Department of Zoology, College of Science, King Saud University, Saudi Arabia.

** Department of Biomedical Science, Faculty of Medicine and Health Sciences, University of Putra, Malaysia.

**** Department of Pathology, Microbiology and Forensic Medicine, Faculty of Medicine, University of Jordan, Jordan.

**** The Research Group program, Deanship of Scientific Research, King Saud University, Saudi Arabia.

The present work was subsidized by the Deanship of Scientific Research at King Saud University for project (RG -1435-040). 
hematological, biochemical, histological and histochemical alterations (Jarrar, 2013; Jarrar et al., 2014), little is known about the morphometric alterations induced by SNPs in relation to size, a point to be clarified in the present work.

\section{MATERIAL AND METHOD}

A total of 42 adult healthy male mice (BALB/C), with an average weight of $25.2 \mathrm{gm}$, obtained from the Animal House, Applied Science University of Jordan were used in the present work. The mice were randomly divided into 6 groups (five test groups and control one) of 7 animals each and housed at room temperature $\left(24 \pm 1^{\circ} \mathrm{C}\right)$ and $12 \mathrm{~h}$ light$12 \mathrm{~h}$ dark and provided with commercial pellets and tap water ad libitum. The tested groups were exposed to intraperitoneal (i.p.) injection with a daily single dose $(1 \mathrm{mg} / \mathrm{kg})$ of SNPs (Sigma-Aldrich, USA) using five different sized-SNPs (10 $\mathrm{nm}, 20 \mathrm{~nm}, 40 \mathrm{~nm} 60 \mathrm{~nm}$ and $100 \mathrm{~nm}$ ) for 35 days, while the members of the control group received a single i.p. injection of aqueous citrate buffer, $\mathrm{pH}=6.2$.

Daily observation throughout the study was made for mortality, food consumption, water intake, change in the body and organs weight and any morphological abnormality. The relative organ weight for the liver, kidney and spleen of each mouse was calculated according to Aniagu et al. (2005), while the relative organ weight and the organ index was calculated according to Sardari et al. (2012). The amount of change on the relative ratio of the organ weight to body weight of mice subjected to different sizes of SNPs \pm Standard deviation (S.D) was calculated. The significant differences between SNPs treated groups and the control one was tested by student $t$-test where $P$ values $<0.05$ were considered statistically significant.

\section{RESULTS}

No mortality was recorded among the members of the all mice groups under study. The followings morphometric alterations were induced by different sizes of SNPs.

Effect of SNPs on the average weight. A non significant decline $(\mathrm{P}$ value $=0.561)$ of the average weight was seen among members receiving $20 \mathrm{~nm}$ SNPs started by the end of fourth week of treatment. On the other hand, the decline of the average weight in the other treated groups was also non significant ( $\mathrm{p}$-value $<0.05$ ) but lower than mice received $20 \mathrm{~nm}$ (Table I and Fig. 1). Control mice had normal weight gain during the treatment period.

Table I. Weekly mouse average weight $(\mathrm{g}) \pm$ standard deviation for each group $(\mathrm{n}=7)$ after treatment with different sizes of SNPs.

\begin{tabular}{lcccccc}
\hline roup & $\begin{array}{c}\text { Starting } \\
\text { weigth }\end{array}$ & First week & Second week & Third week & Fourth week & Fifth week \\
\hline ontrol & $27.7 \pm 1.2$ & $28.5 \pm 3.3$ & $29.3 \pm 3.1$ & $30 \pm 2.8$ & $30.3 \pm 2.9$ & $30.8 \pm 3.2$ \\
) $\mathbf{n m}$ & $27.3 \pm 1.6$ & $28.5 \pm 2.9$ & $28.8 \pm 3.2$ & $29.3 \pm 3.5$ & $29.65 \pm 3.2$ & $30 \pm 3.6$ \\
$\mathbf{l} \mathbf{~ n m}$ & $26.2 \pm 1.9$ & $26.8 \pm 2.1$ & $27.7 \pm 2.5$ & $28.8 \pm 2.7$ & $28.7 \pm 2.5$ & $27.8 \pm 3.1$ \\
$\mathbf{l} \mathbf{~ n m}$ & $27.3 \pm 1.7$ & $28.7 \pm 4.1$ & $29.2 \pm 3.5$ & $29.3 \pm 3.8$ & $30 \pm 4.1$ & $30.4 \pm 4.3$ \\
$\mathbf{I} \mathbf{~} \mathbf{m}$ & $27.8 \pm 1.3$ & $29 \pm 4.5$ & $29.2 \pm 4.7$ & $29.3 \pm 4.3$ & $30 \pm 4.9$ & $30.5 \pm 4.5$ \\
$\mathbf{0} \mathbf{~} \mathbf{n m}$ & $25 \pm 2.2$ & $25.8 \pm 3.2$ & $26.9 \pm 3.7$ & $28 \pm 4.1$ & $28.3 \pm 3.6$ & $28.2 \pm 3.7$ \\
\hline
\end{tabular}

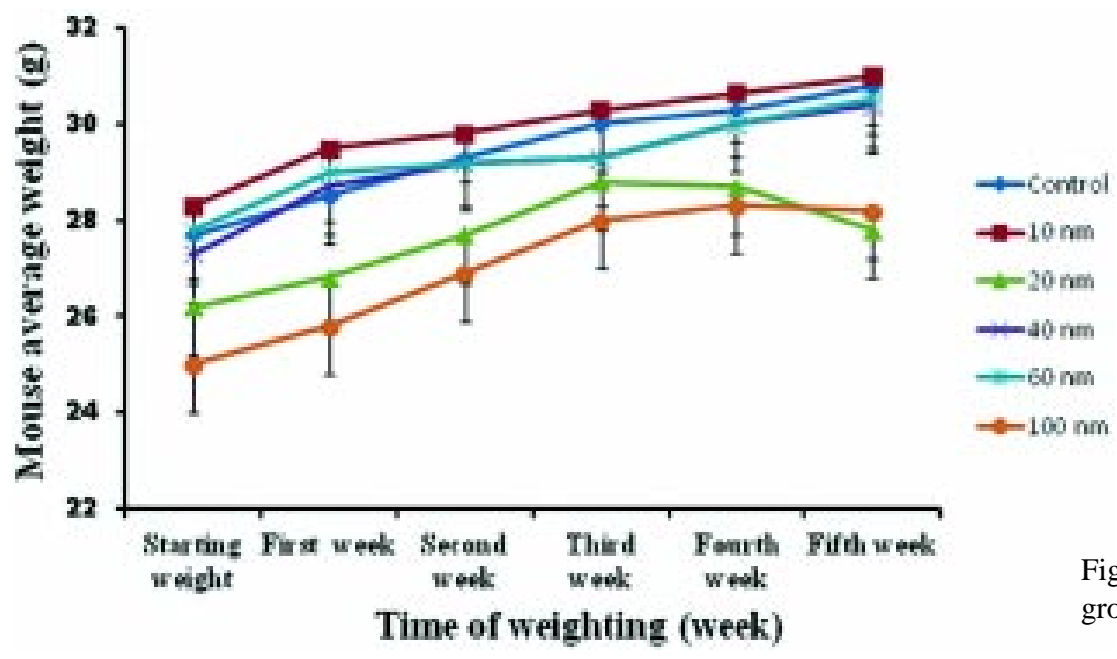

Fig. 1. Weekly mouse average weight (g) for each group after treatment with different sizes of SNPs. 
Effect on food consumption. As seen in both Table II and Figure 2, the amount of food consumed (gram) per gram of body weight gain of the treated groups was slightly less than that of the control group except those exposed to $100 \mathrm{~nm}$ particles. However, mice exposed to $10 \mathrm{~nm}$ SNPs showed significant decline food consumption (18\%) of food consumed per gram of body weight gain than the control mice.

Effect on water intake. As shown on Table III and Figure 3 , water intake $(\mathrm{ml})$ per gram of body weight was increased in all treated mice, except $100 \mathrm{~nm}$ particle treated ones where water consumption was almost similar to that of the control mice.

Effect on the fur color. The color of SNPs treated mice fur became tan in comparison with the white coat of the control mice.

Effect on the eyes: Two mice received $20 \mathrm{~nm}$ SNPs showed unilateral blindness (Fig. 4).

Organs color. The color of the liver, spleen and testes were not affected in SNPs treated mice in comparison with those of the control animals while some (3 out of 7) kidneys of mice received $20 \mathrm{~nm}$ showed faint pale color.
Effect on the liver weight. Mice of all SNPs treated groups showed decrease in the relative ratio of liver weight to body weight (Table IV and Fig. 5). The percentage absolute liver weights were significantly (p-value $=0.0001$ ) decreased in mice receiving $60 \mathrm{~nm}$ SNPs while failed to reach the statistical significance in other treated groups (Fig. 6). On the other hand, three out of seven mice exposed to $20 \mathrm{~nm}$ SNPs showed cholestasis with ballooning of the gall bladder (Fig. 7).

Effect on kidneys weight. Mice of all treated groups, except those subjected to $20 \mathrm{~nm}$ particles, showed decrease on the relative ratio of total kidney weight to body weight and the total kidney index (Table V and Fig. 8). The percentage absolute Kidney weights were significantly decreased in mice receiving $60(\mathrm{p}$-value $=0.001)$ and $100 \mathrm{~nm} \mathrm{SNPs}(\mathrm{p}-$ value $=0.002$ ) while mice exposed to 10 and $40 \mathrm{~nm}$ were less affected (Fig. 9).

Effect on spleen weight. As seen in Table VI and Figure 10 , only member of groups subjected to $10 \mathrm{~nm}$ and $60 \mathrm{~nm}$ particles showed decrease on the relative ratio of spleen weight to body weight and spleen index. However there is a significant decrease in the percentage absolute spleen weight for mice treated with $60 \mathrm{~nm}$ SNPs ( $\mathrm{p}$-value= 0.04) while the other groups showed no significant changes ( $\mathrm{p}$-value $>0.05$, t-test) (Fig. 11).

Table II. Weekly ratio of food consumption $(\mathrm{g})$ to mouse body weight $(\mathrm{g})$ after treatment with different sizes of SNPs.

\begin{tabular}{lcccccc}
\hline $\begin{array}{l}\text { Fifth } \\
\text { week }\end{array}$ & $\begin{array}{c}\text { Fourth } \\
\text { week }\end{array}$ & $\begin{array}{c}\text { Third } \\
\text { week }\end{array}$ & $\begin{array}{c}\text { Second } \\
\text { week }\end{array}$ & $\begin{array}{c}\text { First } \\
\text { week }\end{array}$ & $\begin{array}{c}\text { Starting } \\
\text { weight }\end{array}$ & Group \\
\hline 2.44 & 2.45 & 2.43 & 2.47 & 1.5 & 1.13 & Control \\
2.01 & 2.11 & 2.09 & 2.12 & 1.67 & 1.21 & $10 \mathrm{~nm}$ \\
2.3 & 2.27 & 2.25 & 2.3 & 1.52 & 1.2 & $20 \mathrm{~nm}$ \\
2.24 & 2.32 & 2.1 & 1.68 & 1.09 & 1 & $40 \mathrm{~nm}$ \\
2.23 & 2.16 & 2.09 & 1.99 & 1.35 & 1.1 & $60 \mathrm{~nm}$ \\
2.51 & 2.49 & 2.59 & 2.27 & 2 & 1.3 & $100 \mathrm{~nm}$ \\
\hline
\end{tabular}

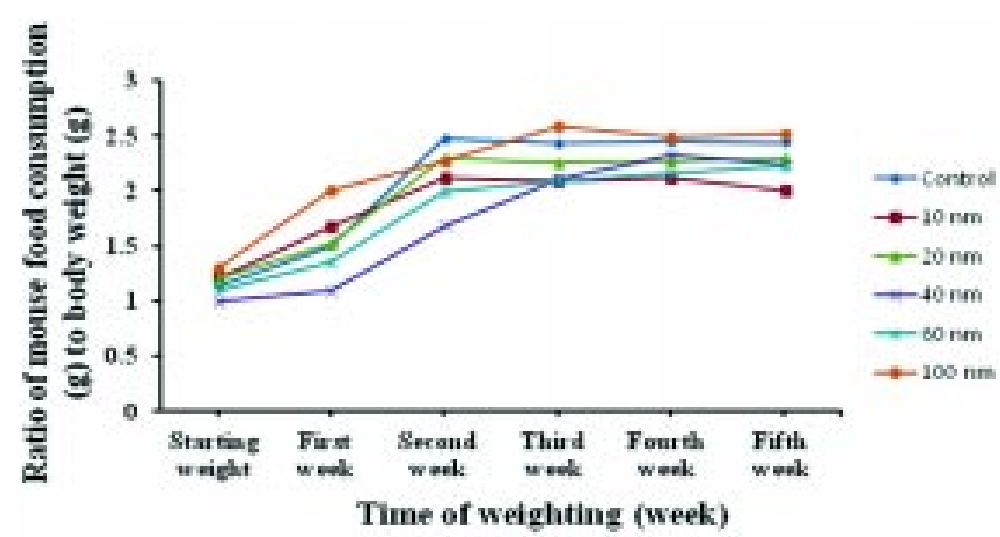

Fig. 2. Weekly ratio of food consumption (g) to mouse body weight (g) after treatment with different sizes of SNP. 
Table III. Weekly Ratio of water intake (ml) to mouse body weight $(\mathrm{g})$ after treatment with different sizes of SNPs

\begin{tabular}{lcccccc}
\hline $\begin{array}{l}\text { Fifth } \\
\text { week }\end{array}$ & $\begin{array}{c}\text { Fourth } \\
\text { week }\end{array}$ & $\begin{array}{c}\text { Third } \\
\text { week }\end{array}$ & $\begin{array}{c}\text { Second } \\
\text { week }\end{array}$ & $\begin{array}{c}\text { First } \\
\text { week }\end{array}$ & $\begin{array}{c}\text { Starting } \\
\text { weight }\end{array}$ & Group \\
\hline 0.66 & 0.64 & 0.6 & 0.78 & 0.55 & 0.44 & Control \\
0.71 & 0.74 & 0.73 & 0.86 & 0.5 & 0.42 & $10 \mathrm{~nm}$ \\
0.76 & 0.75 & 0.78 & 0.83 & 0.44 & 0.4 & $20 \mathrm{~nm}$ \\
0.94 & 0.94 & 0.98 & 1.12 & 0.53 & 0.41 & $40 \mathrm{~nm}$ \\
0.83 & 0.85 & 0.84 & 0.93 & 0.5 & 0.43 & $60 \mathrm{~nm}$ \\
0.65 & 0.68 & 0.67 & 0.64 & 0.46 & 0.4 & $100 \mathrm{~nm}$ \\
\hline
\end{tabular}

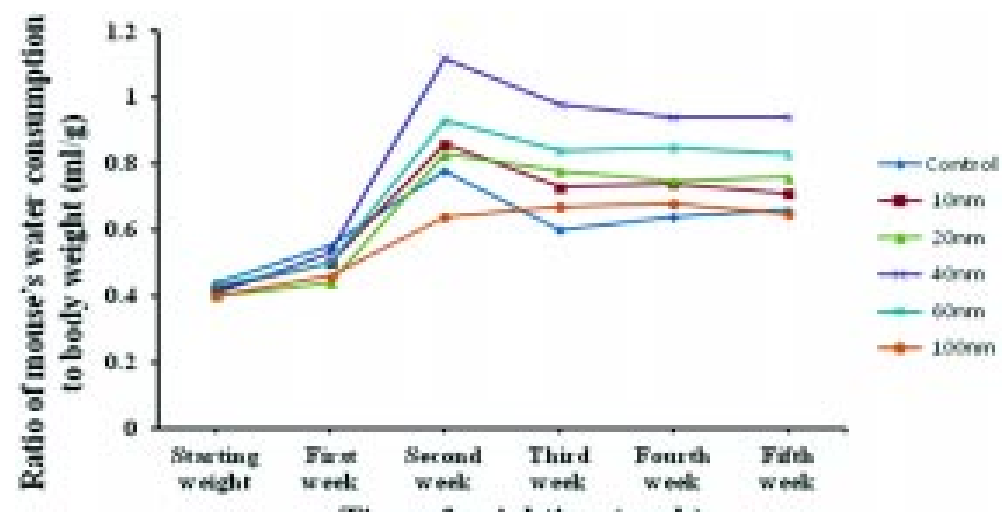

Time of weighting (week)

Fig. 3. Ratio of water intake to mouse body weight $(\mathrm{ml} / \mathrm{g})$ after treatment with different sizes of SNPs

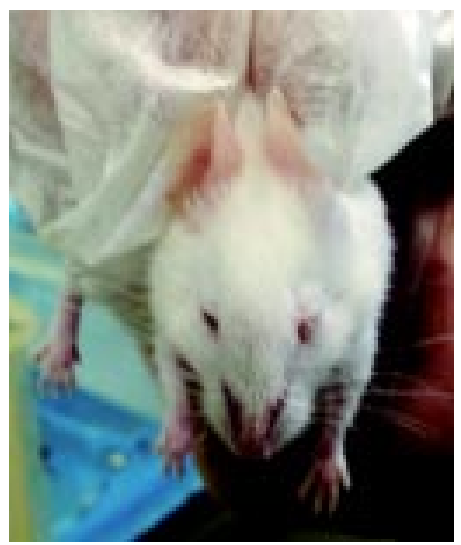

Fig. 4. Unilateral blindness in mouse received $20 \mathrm{~nm}$ SNPs

Table IV. Change on the relative ratio of liver weight to body weight of mice subjected to different sizes of SNPs for 35 days.

\begin{tabular}{lcccc}
\hline Group & $\begin{array}{c}\text { Average liver } \\
\text { weight (g) }\end{array}$ & $\begin{array}{c}\text { Average body } \\
\text { weight (g) }\end{array}$ & $\begin{array}{c}\text { Relative liver } \\
\text { weight (g) }\end{array}$ & $\begin{array}{c}\text { Liver index } \\
\text { (Lx) }\end{array}$ \\
\hline Control group & $1.78 \pm 0.18$ & $30.83 \pm 1.18$ & $5.75 \pm 0.45$ & 1 \\
$\mathbf{1 0} \mathbf{~ n m}$ & $1.57 \pm 0.17$ & $31.03 \pm 2.21$ & $5.08 \pm 0.56$ & 0.88 \\
$\mathbf{2 0} \mathbf{~ n m}$ & $1.48 \pm 0.12$ & $27.77 \pm 3.96$ & $5.38 \pm 0.36$ & 0.94 \\
$\mathbf{4 0} \mathbf{~ n m}$ & $1.61 \pm 0.11$ & $29.57 \pm 3.31$ & $5.44 \pm 0.40$ & 0.95 \\
$\mathbf{6 0} \mathbf{~ n m}$ & $1.45 \pm 0.20$ & $31.27 \pm 2.77$ & $4.7 \pm 0.36^{*}$ & 0.82 \\
$\mathbf{1 0 0} \mathbf{~ n m}$ & $1.60 \pm 0.16$ & $29.51 \pm 1.69$ & $5.4 \pm 0.66$ & 0.94 \\
\hline
\end{tabular}

Significant difference in the percentage absolute liver weight from the control group is represented by “*”, $\mathrm{p}<0.05$, t-test. 
Fig. 5. Liver index for control and SNPs treated groups.
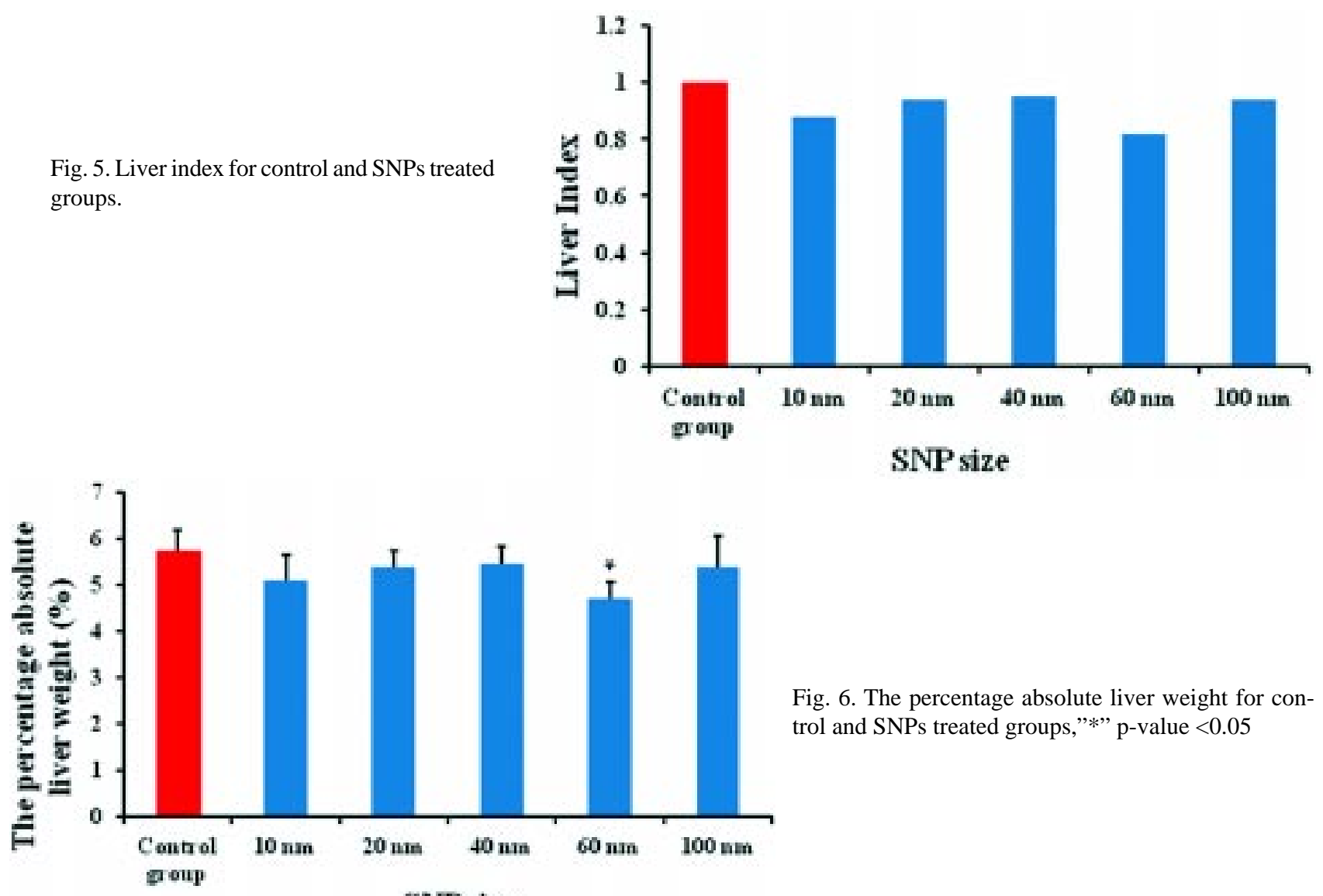

Fig. 6. The percentage absolute liver weight for control and SNPs treated groups,"*” p-value $<0.05$

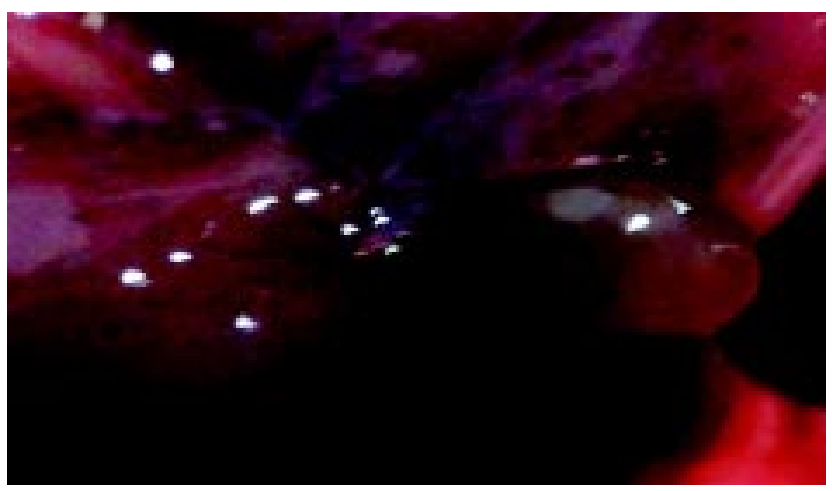

Fig. 7. Light photograph shows cholestasis in mouse treated with $20 \mathrm{~nm}$ SNPs.

Table V. Change on the relative ratio of total kidney weight to body weight of mice subjected to different sizes of SNPs for 35 days

\begin{tabular}{lcccc}
\hline Dose & $\begin{array}{c}\text { Average total } \\
\text { kidney weight }(\mathbf{g})\end{array}$ & $\begin{array}{c}\text { Average body } \\
\text { weight }(\mathbf{g})\end{array}$ & $\begin{array}{c}\text { Relative kidney } \\
\text { weight }(\mathrm{g})\end{array}$ & $\begin{array}{c}\text { Kidney index } \\
\left(\mathbf{K}_{\mathbf{x}}\right)\end{array}$ \\
\hline $\mathbf{C o n t r o l ~ g r o u p ~}$ & $0.43 \pm 0.04$ & $30.83 \pm 1.18$ & $1.39 \pm 0.09$ & 1.0 \\
$\mathbf{1 0} \mathbf{~ n m}$ & $0.40 \pm 0.05$ & $31.03 \pm 2.21$ & $1.30 \pm 0.17$ & 0.94 \\
$\mathbf{2 0} \mathbf{~ n m}$ & $0.41 \pm 0.087$ & $27.77 \pm 3.96$ & $1.48 \pm 0.26$ & 1.06 \\
$\mathbf{4 0} \mathbf{~ n m}$ & $0.38 \pm 0.02$ & $29.57 \pm 3.31$ & $1.28 \pm 0.12$ & 0.92 \\
$\mathbf{6 0} \mathbf{~ n m}$ & $0.37 \pm 0.03$ & $31.27 \pm 2.77$ & $1.18 \pm 0.10^{*}$ & 0.85 \\
$\mathbf{1 0 0} \mathbf{~ n m}$ & $0.37 \pm 0.03$ & $29.51 \pm 1.69$ & $1.24 \pm 0.04^{*}$ & 0.89 \\
\hline Significant difference in the percentage absolute kidney weight from the control group is represented by “*” p<0.05, t-test.
\end{tabular}




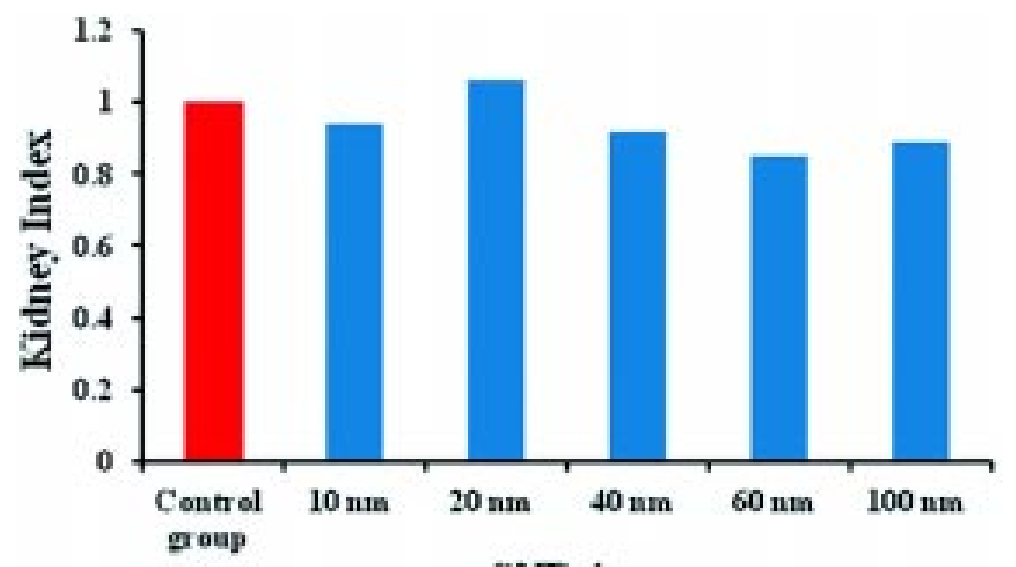

SNP size

Fig. 8. Kidney index for control and SNPs treated groups.

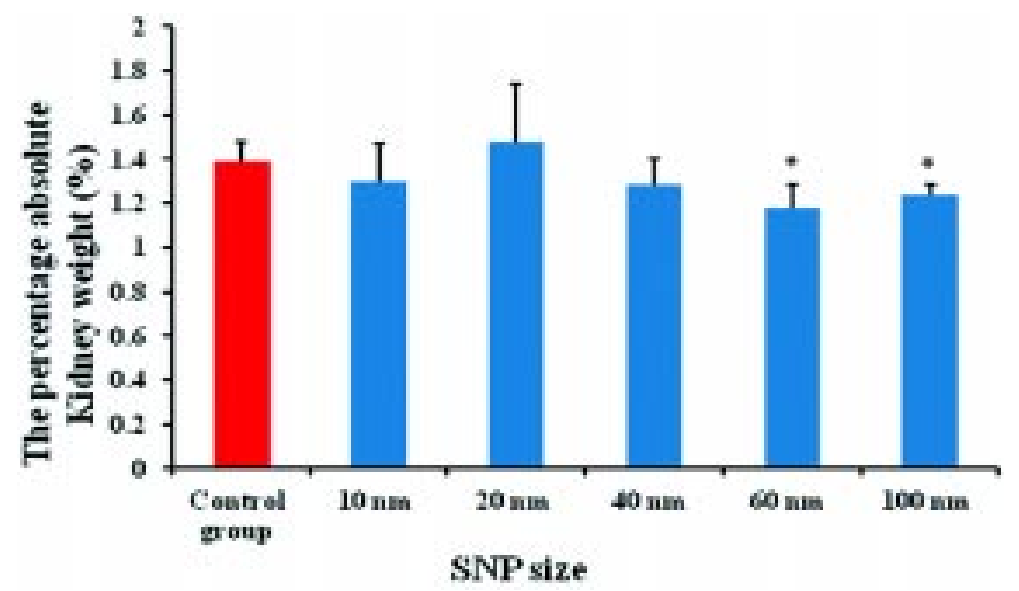

Fig. 9. The percentage absolute kidney weight,"*” p-value $<0.05$.

Table VI. Change on the relative ratio of spleen weight to body weight of mice subjected to different sizes of SNPs for 35 days.

\begin{tabular}{lcccc}
\hline Dose & $\begin{array}{c}\text { Average sple en } \\
\text { weight (g) }\end{array}$ & $\begin{array}{c}\text { Average body } \\
\text { weight (g) }\end{array}$ & $\begin{array}{c}\text { Relative spleen } \\
\text { weight }\end{array}$ & $\begin{array}{c}\text { Spleen index } \\
\left(\mathbf{S}_{\mathbf{x}}\right)\end{array}$ \\
\hline Control group & $0.270 \pm 0.05$ & $30.83 \pm 1.18$ & $0.86 \pm 0.17$ & 1.0 \\
$\mathbf{1 0} \mathbf{~ n m}$ & $0.24 \pm 0.03$ & $31.03 \pm 2.21$ & $0.77 \pm 0.11$ & 0.89 \\
$\mathbf{2 0} \mathbf{~ n m}$ & $0.25 \pm 0.04$ & $27.77 \pm 3.96$ & $0.90 \pm 0.28$ & 1.05 \\
$\mathbf{4 0} \mathbf{~ n m}$ & $0.29 \pm 0.02$ & $29.57 \pm 3.31$ & $0.96 \pm 0.14$ & 1.1 \\
$\mathbf{6 0} \mathbf{~ n m}$ & $0.22 \pm 0.02$ & $31.27 \pm 2.77$ & $0.70 \pm 0.07 *$ & 0.81 \\
$\mathbf{1 0 0} \mathbf{~ n m}$ & $0.27 \pm 0.03$ & $29.51 \pm 1.69$ & p value $=0.04$ & 1.06 \\
\hline
\end{tabular}

Significant difference in the percentage absolute spleen weight from the control group is represented by “*” $\mathrm{p}<0.05$, t-test. 


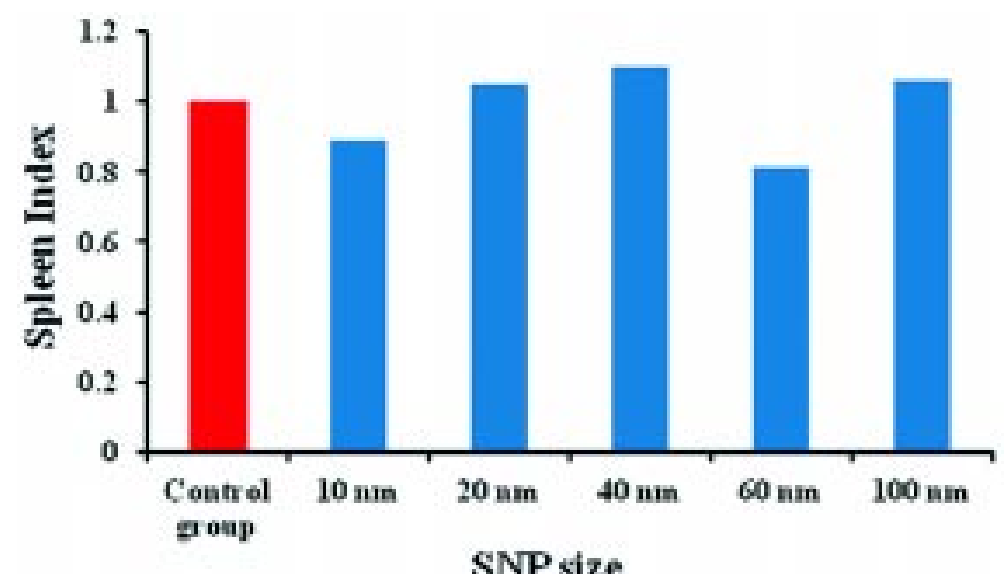

Fig. 10. Spleen index for control and SNPs treated groups.

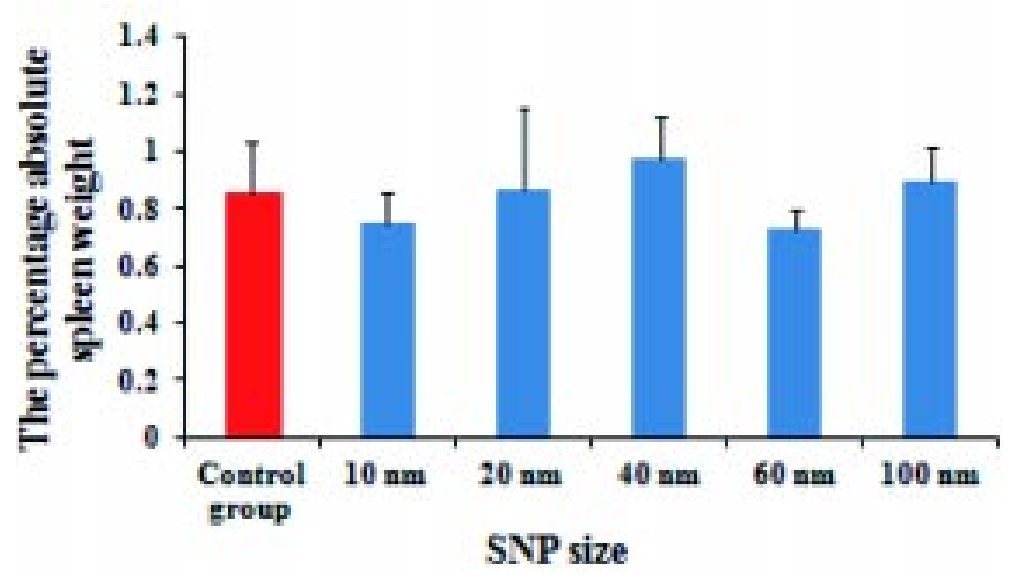

Fig. 11. The percentage absolute spleen weight of control and SNPs treated groups.

\section{DISCUSSION}

Silver NPs have large functional surface area and can have the same dimensions of the biological molecules with the possibility of being adsorbed on the surface of these molecules in the tissue and body fluids (Turtle). These fine particles have unique optical, electrical and thermal properties and are being used in wide range of products for antimicrobial coatings. These together gave SNPs a potential promising as potent constituents of pharmaceutical, medical and industrial products (Pineda et al., 2012).

The morphometric results of the present study showed a decline in the average weight among members of mice receiving $20 \mathrm{~nm}$ SNPs more than the members of other groups. This indicates that this size of SNPs may contribute to cellular toxicity more than the other sizes as a result of oxidative stress pathway and the effect on the oxidative and metabolic enzymes.
Organ weight is one of the most sensitive indicator of toxic agents that reflect impact on the metabolism due to effects on the health and immunological status of the body (Bailey et al., 2004). Mice exposed to variable sizes of SNPs exhibited a decline in the organs under study (liver, total kidneys and spleen) indices. This finding is in agreement with the report of Sardari et al. where oral treatment of rats with SNPs $(70 \mathrm{~nm})$ for 30 days $(2 \mathrm{mg} / \mathrm{kg}$ ) caused spleen atrophy with index of 0.78 while in the present study, mice treated with $60 \mathrm{~nm}$ SNPs for 35 days $(1 \mathrm{mg} / \mathrm{kg}$ ) exhibited spleen index of 0.81 .

The macroscopic observations carried out in the present work reported cholestasis and unilateral blindness in some mice treated by $20 \mathrm{~nm}$ SNPs. The induction of cholestasis might indicate liver injury that leads to impairment of bile flow. Cholestasis is a pattern of 
hepatotoxicity and can be associated with an elevation of alkaline phosphatase and liver necrosis (Kaplowiz, 2004; Singh et al., 2011). Moreover, unilateral blindness seen in some SNPs treated mice might indicate an optic alterations induced by these ultrafine particles which was not reported before.

The morphometric abnormalities, as seen in the present work reveal that smaller SNPs are more toxic than the larger ones. Smaller NPs have much greater surface area to volume and have longer circulating residue than the larger ones with more potential particle size toxicity that could be related to dissolution rate, reactive surface area and bioavailability. Several toxicological reports indicated that SNPs oxidative dissolution is size related where smaller particle release more silver actions due to their greater surface area to mass ratio (Ma et al., 2012). In addition, oxidative dissolution of smaller particles produces more hydrogen peroxide and depletes more dissolved oxygen and protons leading to intracellular ROS generation (Liu \& Hurt, 2010).

\section{CONCLUSION}

It is concluded from the findings of the present study that SNPs can induce several morphological alterations in vital organs of the body. The results suggest more toxic effects of $10 \mathrm{~nm}$ and $20 \mathrm{~nm}$ SNPs than the larger ones.

\section{ACKNOWLEDGEMENTS}

The authors would like to extend their sincere appreciation to the Deanship of Scientific Research at King Saud University for its funding this project (RG-1435-040).

ALMANSOUR, M.; JARRAR, Q.; BATTAH, A. \& JARRAR, B. Alteraciones morfométricas inducidas por la toxicidad de diferentes tamaños de nanopartículas de plata. Int. J. Morphol., 33(2):544-552, 2015.

RESUMEN: Poco se sabe acerca de las alteraciones morfométricas inducidas por la toxicidad de las nanopartículas de plata (NPP). El objetivo fue investigar el efecto del tamaño variable de las NPP en diferentes parámetros morfométricos. Ratones machos adultos sanos (BAL/C) fueron sometidos a diferentes NPP de diferentes tamaños durante 35 días (10 nm, $20 \mathrm{~nm}, 40 \mathrm{~nm} 60 \mathrm{~nm}$ y $100 \mathrm{~nm}$, respectivamente). Las NPP causaron una disminución no significativa del peso promedio, una disminución significativa en el consumo de alimentos, un aumento de la ingesta de agua, ceguera unilateral, cambios en el color de piel y colestasis junto con una disminución en el tamaño promedio del hígado, riñón y el peso del bazo, en relación al peso corporal. Los ratones sometidos a $10 \mathrm{~nm}$ y $20 \mathrm{~nm}$ fueron más afectados que los ratones que recibieron las nanopartículas más grandes. Estos resultados pueden indicar que las NPP podrían inducir alteraciones morfométricas que están relacionadas con el tamaño, en las cuales las NPP más pequeñas tienen un mayor impacto que las más grandes.

PALABRAS CLAVE: Nanopartículas de plata; Morfología; Toxicología; Hígado; Riñon; Bazo.

\section{REFERENCES}

Ahamed, M.; Alsalhi, M. \& Siddiqui, M. K. Silver nanoparticle applications and human health. Clin. Chim. Acta, 411(2324):1841-8, 2010.

Aniagu, S. O.; Nwinyi, F. C.; Akumka, D. D.; Ajoku, G. A.; Dzarma, S.; Izebe, K. S.; Ditse, M.; Nwaneri, P. E. C.; Wambebe, C. \& Gamaniel, K. Toxicity studies in rats fed nature cure bitters. Afr. J. Biotechnol., 4(1):72-8, 2005.

Austin, C. A.; Umbreit, T. H.; Brown, K. M.; Barber, D. S.; Dair, B. J.; Francke-Carroll, S.; Feswick, A.; Saint-Louis, M. A.; Hikawa, H.; Siebein, K. N. \& Goering, P. L. Distribution of silver nanoparticles in pregnant mice and developing embryos. Nanotoxicology, 6:912-22, 2012.

Bailey, S. A.; Zidell, R. H. \& Perry, R. W. Relationships between organ weight and body/brain weight in the rat: what is the best analytical endpoint? Toxicol. Pathol., 32(4):448-66, 2004.

Hanson, J. Nano silver legal petition: 300 nano silver products. Washington, International Center for Technology Assessment, 2011.

Jain, J.; Arora, S.; Rajwade, J. M.; Omray, P.; Khandelwal, S. \& Paknikar, K. M. Silver nanoparticles in therapeutics: development of an antimicrobial gel formulation for topical use. Mol. Pharm., 6(5):1388-401, 2009.

Jain, P. \& Pradeep, T. Potential of silver nanoparticle-coated polyurethane foam as an antibacterial water filter. Biotechnol. Bioeng., 90(1):59-63, 2005.

Jarrar, Q. B. Silver nanoparticles toxicity: size effect. Thesis Master Degree in Analytical Toxicology. Jordan, University of Jordan, 2013. 
Jarrar, Q.; Battah, A.; Obeidat, F. \& Battah, K. Biochemical changes induced by the toxicity of variable sizes of silver nanoparticles. Brit. J. Pharm. Res., 4(24):2670-8, 2014.

Johnston, H. J.; Hutchison, G.; Christensen, F. M.; Peters, S.; Hankin, S. \& Stone, V. A review of the in vivo and in vitro toxicity of silver and gold particulates: particle attributes and biological mechanisms responsible for the observed toxicity. Crit. Rev. Toxicol., 40(4):328-46, 2010.

Kaplowitz, N. Drug-induced liver injury. Clin. Infect. Dis., 38 Suppl. 2:S44-8, 2004

Kim, J. S.; Kuk, E.; Yu, K. N.; Kim, J. H.; Park, S. J.; Lee, H. J.; Kim, S. H.; Park, Y. K.; Park, Y. H.; Hwang, C. Y.; Kim, Y. K.; Lee, Y. S.; Jeong, D. H. \& Cho, M. H. Corrigendum to "Antimicrobial effects of silver nanoparticles" [Nanomed Nanotechnol Biol Med. 2007;1:95-101]. Nanomed. Nanotechnol. Biol. Med., 10(5):1119, 2014.

Liu, J. \& Hurt, R. H. Ion release kinetics and particle persistence in aqueous nano-silver colloids. Environ. Sci. Technol., 44(6):2169-75, 2010.

Luoma, S. N. Silver nanotechnologies and the environment: old problems or new challenges? Washington D. C., Woodrow Wilson International Center for Scholars, Project on Emerging Nanotechnology, 2008.

Ma, R.; Levard, C.; Marinakos, S.; Cheng, Y.; Liu, J.; Michel, F. M.; Brown, G. E. \& Lowry, G. V. Size-controlled dissolution of organic-coated silver nanoparticles. Environ. Sci. Technol., 46(2):752-9, 2012.

Oberdörster, G.; Stone, V. \& Donaldson, K. Toxicology of nanoparticles: A historical perspective. Nanotoxicol., 1(1):2$25,2007$.

Pineda, L.; Chwalibog, A.; Sawosz, E.; Lauridsen, C.; Engberg, R.; Elnif, J.; Hotowy, A.; Sawosz, F.; Gao, Y.; Ali, A. \& Moghaddam, H. Effect of silver nanoparticles on growth performance, metabolism and microbial profile of broiler chickens. Arch. Anim. Nutr., 66(5):416-29, 2012.

Rai, M. K.; Deshmukh, S. D.; Ingle, A. P. \& Gade, A. K. Silver nanoparticles: the powerful nanoweapon against multidrugresistant bacteria. J. Appl. Microbiol., 112(5):841-52, 2012.

Reijnders, L. Cleaner nanotechnology and hazard reduction of manufactured nanoparticles. J. Clean. Prod., 14(2):124-33, 2006.

Sardari, R. R. R.; Zarchi, S. R.; Talebi, A.; Nasri, S.; Imani, S.; Khoradmehr, A. \& Sheshde, S. A. R. Toxicological effects of silver nanoparticles in rats. Afr. J. Microbiol. Res., 6(27):558793, 2012.

Silver, S.; Phung Ie, T. \& Silver, G. Silver as biocides in burn and wound dressings and bacterial resistance to silver compounds. J. Ind. Microbiol. Biotechnol., 33(7):627-34, 2006.

Singh, A.; Bhat, T. K. \& Sharma O. P. Clinical biochemistry of hepatotoxicity. J. Clin. Toxicol., S4:001, 2011.

Tuttle, G. R. Size and surface area dependent toxicity of silver nanoparticles in zebrafish embryo (Danio rerio). Master Thesis in toxicology. Oregon, Oregon State University, 2012.

Vigneshwaran, N.; Kathe, A. A.; Varadarajan, P. V.; Nachane, R. P. $\&$ Balasubramanya, R. H. Functional finishing of cotton fabrics using silver nanoparticles. J. Nanosci. Nanotechnol., 7(6):18937, 2007.

Xue, Y.; Zhang, S.; Huang, Y.; Zhang, T.; Liu, X.; Hu, Y.; Zhang, Z. \& Tang, M. Acute toxic effects and gender-related biokinetics of silver nanoparticles following an intravenous injection in mice. J. Appl. Toxicol., 32(11):890-9, 2012.

\author{
Correspondence to: \\ Qais B. Jarrar \\ Department of Biomedical Science \\ Faculty of Medicine and Health Sciences \\ University of Putra \\ MALAYSIA
}

Email: jarrarq@yahoo.com

Received: 22-11-2014

Accepted: 09-02-2015 